Meta

Journal des traducteurs

Translators' Journal

\title{
The Present Status of Screen Translation in China
}

\section{Shaochang Qian}

Volume 49, numéro 1, avril 2004

Traduction audiovisuelle

Audiovisual Translation

URI : https://id.erudit.org/iderudit/009019ar

DOI : https://doi.org/10.7202/009019ar

Aller au sommaire du numéro

Éditeur(s)

Les Presses de l'Université de Montréal

ISSN

0026-0452 (imprimé)

1492-1421 (numérique)

Découvrir la revue

Citer cet article

Qian, S. (2004). The Present Status of Screen Translation in China. Meta, 49(1), 52-58. https://doi.org/10.7202/009019ar
Résumé de l'article

À partir de sa propre expérience, l'auteur donne un aperçu de l'évolution récente du doublage et du sous-titrage au cinéma et sur les chaînes de télévision de la Chine continentale. Les changements rapides, surtout depuis 1978, affectent la qualité des traductions, en particulier celle du doublage.
Ce document est protégé par la loi sur le droit d'auteur. L’utilisation des services d’Érudit (y compris la reproduction) est assujettie à sa politique d'utilisation que vous pouvez consulter en ligne.

https://apropos.erudit.org/fr/usagers/politique-dutilisation/ 


\title{
The Present Status of Screen Translation in China
}

\author{
SHAOCHANG QIAN \\ Shanghai International Studies University, Shanghai, China \\ scqian@public6.sta.net.cn
}

\section{RÉSUMÉ}

À partir de sa propre expérience, l'auteur donne un aperçu de l'évolution récente du doublage et du sous-titrage au cinéma et sur les chaînes de télévision de la Chine continentale. Les changements rapides, surtout depuis 1978, affectent la qualité des traductions, en particulier celle du doublage.

\section{ABSTRACT \\ In a personal style, the author gives an overview of the recent past and the present status of screen translation in Mainland China. The audiovisual landscape has changed quickly, especially since 1978 . The quality of dubbing is now in a vicious circle. \\ MOTS-CLÉS/KEYWORDS \\ audiovisual translation policy, Mainland China, film distribution, minority languages, TV dubbing}

In this presentation, "China" means "Mainland China." The author is in no position to talk about screen translation in Hong Kong or Taiwan.

\section{Screen translation before 1949}

Before 1949, Mainland China virtually has no screen translation. There was no television. In some theatres in a few major cities, moviegoers who did not know foreign languages might listen to simultaneous interpretation through earphones attached to the seat when watching foreign films, almost all of them came from Hollywood. In old Shanghai, as I recall, only some big cinemas such as Cathay, Grand, Majestic and Roxy had simultaneous interpretation facilities. But listening to the simultaneous interpretation was no great pleasure, for the interpretation was usually poor and frequently interrupted.

\section{Dubbing and subtitling}

Generally speaking, China's mainland studios and TV stations do not subtitle films. Mainlanders sometimes watch subtitled western films imported from Hong Kong, Taiwan or Singapore. But most of them prefer dubbed films to subtitled ones. The reasons are as follows:

- Most of China's mainlanders are poor in foreign languages. A few years ago, I conducted a little quiz at a class of ten English major graduate students to test their level of listening comprehension. I asked them to translate into Chinese a short passage of dialogue 
lasting for only one minute chosen from an American TV story Falcon Crest. I first explained to them the roles of the three main characters: Angie, Jason and Richard, and their interrelations. Then I played for them the videotape of the passage three times. The result showed their rate of comprehension ranged from $50 \%$ to $80 \%$. And in Mainland China, the English major postgraduates of the Shanghai International Studies University are regarded by the public as very strong in English, so you can imagine the level of English of the general public.

Before 1949, English was a required course in most high schools. After 1949, especially after the Korean war that began in 1950, Russian language replaced English. And when China and the Soviet Union became enemies in the early 60s, foreign languages were no longer taught in most schools. China gradually resumed English teaching after opening to the outside, but the listening and speaking abilities of most English-learners are poor for lack of practice. Chinese, including government leaders, are now increasingly aware of the importance of English, and a nationwide English-learning campaign is now going on. On July 2001, China's English language national newspaper China Daily carried a report describing the Mainland's English learning craze: "Tens of thousands of people across China, ranging from young kids to the mayor of Beijing and senior State leaders, have discovered new and very practical reasons for learning English. The catalyst was the decision made on July 13 by the International Olympic Committee to award Beijing the right to host the 2008 Summer Olympic Games.” But it will take years for most Mainlanders to speak good English.

- Subtitles distract the audience's attention since it's necessary to read the subtitles while watching the picture.

- When the characters in a picture are speaking quickly, the audience is unable to catch up with the long subtitles that are full translations of the dialogue, so the subtitles must be condensed, and are less vivid and entertaining than dubbing.

- China still has a considerable number of illiterates and semi-literates who cannot read subtitles.

- The ethnic minorities living in Tibet, Inner Mongolia and Xinjiang Uighur Autonomous Region have their own languages that are totally different from Chinese. Those educated ones can now listen to Chinese, but most of them still have difficulty reading Chinese.

During the last decade, however, some studios and television stations began to provide subtitled western pictures for those who know English and for English learners. The Shanghai TV station, for example, a few years ago started airing subtitled pictures in its English News Service of STV Channel 2, now known as IBS (International Broadcasting Service).

\section{Screen translation before 1978}

In early 1949, the Changchun Film Studio of Northeast China started film dubbing.

The Changchun Studio, the biggest of its kind in the Northeast China, was actually set up by the Japanese army during its occupation from 1931 to 1945 . The reason that Changchun was number one in film dubbing was because Northeast China was liberated by the People's Liberation Army in early November of 1948 when the rest of China was still in the hands of the Kuomintang regime. After Mainland China was fully liberated by the end of 1949, Beijing and Shanghai began to dub movies too. In 1950, the Shanghai Film Studio set up a dubbing department and dubbed its first film which was a Russian one entitled The Little Hero. 
In 1957, the Dubbing Department became an independent dubbing studio, the first and so far the only independent film dubbing studio in Mainland China. The Studio, which has its own translators as well as dubbing actors and actresses, dubs approximately three-fourths of all imported movies, which is a quota set by the governmental institution, namely, the China Film Distribution Company. The remaining one-quarter of imported movies are dubbed by other film studios, mainly Changchun, Beijing, Bayi (Army), Emei (Sichuan) and Zhujiang (Guangdong). But for reasons known to all, prior to 1978 there were only a limited number of imported movies, coming mainly from the Soviet Union and other East European countries. And during the decade of the Cultural Revolution from 1966 to1976, the only foreign movies all mainlanders were allowed to watch were two Russian films: Lenin in October and Lenin in 1918. These were shown continuously and repeatedly in all movie theatres around China.

TV stations began to appear in Mainland China in the 1950s. The first one, which came into being on May 1, 1958, was the Beijing Television Station, predecessor of the present Central TV Station (CCTV), while the Shanghai TV Station (STV) made its appearance on October 1, 1958. Later a few other major cities also established TV stations. But there was no TV translation before the 80 s, so the stations occasionally provided the audience with movies dubbed by film studios. However, all TV stations had only two channels, one central and one local. I would like to explain in this connection that unlike in the United States, where television viewers throughout the country can watch $\mathrm{ABC}, \mathrm{NBC}, \mathrm{CBS}$ and $\mathrm{CNN}$ programmes, in Mainland China the CCTV is the only national TV network that enjoys nationwide coverage and all local stations are affiliated to CCTV. Local stations then produced very few programmes of their own. With most of their programmes coming from CCTV, local stations used to offer only local news and public affairs programmes. The TV audience was relatively small since television sets were a big luxury for most families before China embarked on reform in 1978. For example, when the Shanghai TV Station came into being in 1958, there were fewer than 100 TV sets in all of Shanghai.

\section{Screen translation after 1978}

\subsection{Movies}

After China opened itself to the outside world in 1978, there began a continuous boom of screen translation as a result of looser control over the import of foreign movies. There are, however, some restrictions. The China Film Distribution Company, which is China's sole movie import and distribution institution, generally adheres to the following principles when importing of foreign films:

- The Company introduces only what it regards as "good" films

- Overflow of foreign movies is avoided

- Movies that contain violence, pornography, political or religious propaganda are excluded

- The Company stipulates that American films not exceed 50\% of all imported movies.

Though politics no longer plays such a huge role in the choice of foreign films as it did during the Cultural Revolution, it is still an important factor. As M. Zhao Huayong, Director of the International Department of CCTV, said at the 1999 national conference on television: 


\begin{abstract}
"Imported films must not exceed 50\%. We should try to import more films from other countries to ensure proper balance. Otherwise problems may arise. There was a time when Sino-US relations suddenly intensified. We had a big trouble then. We could immediately stop broadcasting American news, but what could we do with American pictures? At that time our entertainment programmes were filled with American teleplays, and we didn't have enough pictures from other countries to fill the gap. That was a real problem. Finally we were obliged to cancel the American pictures and replace them with poorer ones from other countries or rebroadcast those that had already been broadcast. Had we controlled the proportion of imported films, the situation would have been better. This is a problem of proportion. It is a lesson learned by the Central TV Station. Local stations across the country can also learn from it."
\end{abstract}

From 1957 to 1999, the Shanghai Film Dubbing Studio dubbed more than 1000 feature films. During that time, a large number of documentaries, cartoons and popular science films were also dubbed. Paying attention to the problem of proportion, films are imported from 48 countries. The foreign languages include English, Russian, French, German, Spanish, Italian, Indian, Arabic, Japanese, Korean, Albanian and Vietnamese. As the Studio does not have enough translators for all these languages, it often gets professional help from universities and other institutions. Besides translating foreign movies into Chinese, the Studio also translates Chinese films into foreign languages. But in the latter case, it only subtitles, because it has difficulty finding actors and actresses who are fluent in foreign languages. At present, all Chinese films that are exported or intended for international film festivals are always subtitled in English, but never dubbed. And many studios are now doing this subtitling themselves. Unfortunately, some of it is rather shoddy. This is one of the factors affecting the box office and sales of Chinese films in international markets.

As is well-known, the standard spoken Chinese is Mandarin, which has always been popularized throughout the country by governments at all levels. Nevertheless, a considerable proportion of Chinese, particularly the inhabitants of the Southern provinces of Guangdong and Guangxi, do not fully understand Mandarin. The Cantonese dialect they speak is so different from Mandarin that people from these two provinces often have problems communicating with those from other provinces of China. So one of the tasks of the Shanghai Film Dubbing Studio is translating films in Mandarin into Cantonese. China is made up of 56 nationalities. Some of the national minorities have their own languages. There are mainly Mongolians, Tibetans, Uighurs (of Xinjiang Uighur Autonomous Region) and Koreans. Thus, the Studio has the additional work of translating films in Chinese into Mongolian, Tibetan, Uighur and Korean.

\title{
4.2. Television
}

In 1995 the television coverage of China's mainland was $84.8 \%$ of its more than 1.2 billion population, and the proportion has been rising steadily. So the television audience is enormous. Most of the country's television dubbing has been done by CCTV and STV. Not long after China opened to the outside world (1978), the International Department of CCTV initiated television dubbing in 1980. Immediately following CCTV, STV too started TV dubbing in 1981. CCTV has its own translators, dubbing directors, dubbing actors and actresses. The STV does not have translators of 
its own, but it constantly gets professional help from translators working at universities or other institutions (myself being one of them).

In the beginning, the number of dubbed pictures was limited, but shot up rapidly. The CCTV dubbed only 200 episodes of TV plays between 1980 and 1985, averaging less than one episode per week. But from 1985 to 1992 CCTV provided viewers with 200-300 hours of newly-dubbed television programmes and movies, reaching an average of three to five hours a week. The current figure has risen to around eight hours a week. And the dubbed teleplays and made-for-television-films are broadcast on five of the eight channels, namely CCTV1, CCTV2, CCTV3, CCTV6 and CCTV8. The Shanghai TV Station has also done a tremendous amount of dubbing work. As its dubbed foreign movies were greatly welcomed by the audience, it was obliged to dub more and more imported films. To deal with the new situation, STV formed an independent dubbing department in 1987. Over the past decade, the Dubbing Department of STV has dubbed 3,500 hours of TV plays and movies, an average of six to seven hours per week.

Of that imported for television, Hollywood pictures are the mainstay. For example, in 1997, CCTV offered 177 newly-dubbed TV plays and movies, 103 of them from Hollywood, amounting to 58.75 of the total.

Most of the imported movies are average ones. Statistics show, in 1997, that the Central and provincial TV stations of Mainland China dubbed and aired some 2,000 hours of TV plays and movies, of which $66 \%$ were soap operas, action films and sitcoms. Needless to say, the bulk were from Hollywood. In that year, the CCTV offered 177 newly-dubbed TV plays and movies. (In this case, one TV series is regarded as one play). Of the 177,103 were American, comprising $58.75 \%$ of the total. And in 1998, 78 of the 147 dubbed TV plays and movies were from Hollywood (53\%). The rest of the imported pictures come mainly from Japan, South Korean, Russia, France, Germany, Italy, Britain, India, Mexico and Brazil.

While in Mainland China, the importing of movies is monopolized by the China Film Distribution Company, the control over the introduction of TV plays is less strict. Seeing that CCTV and STV were garnering considerable fame from television dubbing as well as substantial profits from the commercials attached to those programmes, many local TV stations began to look in this direction too. Beginning in the early 90s, local stations, including those at provincial and municipal levels, gradually found ways to import TV plays and began film-dubbing, too. It is difficult to cite statistics in this paper because there are so many local stations and so many different ways of obtaining foreign movies. Generally speaking, both the quality and quantity of their products are lower than those of CCTV and STV.

\section{Box offices and ratings of foreign pictures}

When the doors of Mainland China suddenly opened to the outside world, the mainlanders were surprised to find such a colorful world out there. Everything they saw in foreign pictures was new and fun. As a result, the box offices and ratings were naturally very high in the initial period.

The box offices for Hollywood films such as Jurassic Park, Saving Private Ryan, Titanic and Gladiator, were incomparable. And because of the huge cost and highlyadvanced technology used in shooting these movies, they have always been able to 
attract large audiences, so their box offices still remain very high to this day. Take for example the newly introduced picture Pearl Harbor. When the movie had its premiere at the Shanghai Film Art Centre (August 8, 2001), the theatre enjoyed three consecutive days of full houses and the box office hit the theatre's record high of RMB 600,000 yuan (USD 72,000). Its top ticket was RMB 100 yuan (USD 12), which is fairly high for local consumers.

But the situation with the ratings for foreign television is different. Again I would like to choose as an example the situation in Shanghai with which I am more familiar. Compared with the number of TV viewers, that of moviegoers is very small. All middle-aged and more elderly Shanghainese have a vivid memory of what happened in 1981 when STV showed in its prime time the Japanese TV series Sugata Sansilo, the first foreign TV play aired in Shanghai's history. Though it was just a mediocre TV series about Japanese martial art judo, it created a stupendous sensation. All of Shanghai nearly went mad. Movie theatres and other entertainment centers were virtually empty. Shanghai's main shopping street, Nanjing Road, normally bustling and packed with shoppers and pedestrians, suddenly turned quiet and desolate. Everybody was watching Sugata Sansilo. They either flocked to those families who owned TV sets or swarmed in front of TV screens in the show windows of stores. There were no ratings of this TV series, simply because China did not know how to calculate ratings at that time.

A few years later, Hollywood television came. The American soap operas, sitcoms and action films that began to appear on Shanghai's television screens in the late 80s attracted huge audiences. Pictures like Falcon Crest, Hunter, Hotel and Growing Pains all enjoyed ratings above $30 \%$. But the ratings of dubbed TV plays have been falling since the middle $90 \mathrm{~s}$. At present very few foreign TV plays reach ratings above $5 \%$. The following factors may account for the fall:

- Chinese audiences have gradually lost their curiosity about foreign pictures which used to be their only channel to know the outside world. Mainlanders now can read foreign magazines, buy foreign commodities and go abroad to take pleasure trips, see friends and relatives, do business or attend meetings.

- Foreign pictures are no longer so rare as they used to be. With the rapid increase of amount of imported TV plays and films, Chinese TV viewers now have a much greater variety of shows to choose from. The case is different with foreign motion pictures, which are still limited to around 40 annually.

- Mainlanders now have many other forms of recreation besides watching TV, which was almost the only outlet in the past.

- Chinese audiences have more demanding taste in their appreciation of movies, so they have become more choosy.

- Generally, there has been a gradual decline in the quality of imported pictures.

- To protect the domestic television industry, the government has ordered that all imported pictures should not be shown during the prime time (7 to 9:30 pm).

A few months ago Shanghai's governmental administration in charge of movies and television decided to merge the Dubbing Department of STV with the Shanghai Dubbing Studio. But up to the present (August 2001), the merger has not taken place yet.

Currently, television dubbing in China is in a vicious circle. With the fall in ratings, producers are getting less commercials and hence less money. With less money, 
they are importing poorer foreign TV plays and giving lower pay to translators. But good translators are reluctant to translate poor television programmes for low pay. So the quality of dubbing is declining, which further affects ratings.

\section{EDITOR'S NOTE}

Qian was previously a medical doctor prior to the Cultural Revolution, during which he was badly persecuted. Later he was forced to switch to English teaching, as he had received education at Western schools. He is currently professor of translation at the College of Journalism and Communications, Shanghai International Studies University. He has translated several novels and more than 700 hours of movies and TV plays, including those that enjoy very high ratings, such as Falcon Crest, Dynasty, Growing Pains, Roots, The Thorn Birds, Casablanca, Scarlet, Outbreak, Napoleon and Josephine, Crash Dive, The Last Days of Patton, The May Flower, Heaven and Hell, Legend in Fall, etc.

This paper was first given on October 18, 2001 at the International Conference held in Hong Kong on Dubbing and Subtitling in a World Context. 